\title{
THE RESEARCH OF EFFECTS THAT CAPITAL STRUCTURES HAD ON OPERATING PERFORMANCE OF COMMERCIAL BANKS
}

\author{
Zhe Cui \\ Nantong University, P.R.China \\ Guohua Wang* \\ Nantong University, P.R.China
}

\begin{abstract}
Capital structure is directly related to the operating performance of commercial banks. Thus, the effect that a capital structure had on the operating performance draws the attention of the industry and academia. This paper used SPSS19.0 software, selected return on assets, non-performing loan ratio, liquidity ratio from the first quarter of 2011 to the third quarter of 2015 of commercial banks as indexed to measure operating performance, selected assets-liability ratio, core (tier 1) capital adequacy ratio and capital adequacy ratio of commercial banks as factors in calculation, used factor analysis to get comprehensive operating performance of banks, built regression models of capital structure, comprehensive operating performance and subentry of operating performance to conduct empirical analyses, analyzed the effect that capital structures had on operating performance of banks and worked out profit, capital and correspondent liquidity.
\end{abstract}

Keywords: Commercial bank; Capital structure; Operating performance

JEL code: M0 


\section{Introduction}

\subsection{Background of the subject and current situation}

At present, the feature that domestic economy is in the "new normal" is becoming increasingly obvious. The tendency that domestic economy form upgrades, division complicates and structure rationalizes will be more outstanding. At the same time, economy across the country develops rapidly. Keeping a reasonable capital structure to enhance the ability of banks to resist the risk has become the footstone of commercial banks to maintain healthy sustainable development in current economic situation. However, according to the statistics mentioned in $<2015$ China's regional financial operation report $>$ and the contents showed by China Banking Regulatory Commission, banking financial institutions had obvious development in scale, amount of staff and capital of salary in 2015, at the same time, non-performing loan ratio raised continuously. There were 234000 financial institution networks and about 4053000 employees, total assets was about 16900000000 yuan in 2015, with year-on- year growth of 9200, 163000 people and 11.4\%, which intuitively showed that overall operating performance of commercial banks was poor. While keeping a reasonable capital structure and enhancing the ability of banks to resist the risk, the effect that a capital structure had on the bank's performance draw the attention of the industry and academia.

Miao Jiuzhi and Dong Jiagang(2011) considered that each state-owned commercial bank only had one stockholder, at the same time, it would be faced with a serious fund shortage which lead to lower capital adequacy ratio and so on. It's time to seize the opportunity to develop business and government should agree that domestic and foreign investment staff go about investing in banks and try theie best to improve capital structures of banks.

$\mathrm{Li} \mathrm{Li(2014)} \mathrm{considered} \mathrm{that} \mathrm{simple} \mathrm{economic} \mathrm{grant} \mathrm{was} \mathrm{not} \mathrm{enough,} \mathrm{it} \mathrm{was} \mathrm{necessary} \mathrm{to} \mathrm{adjust}$ its structure and reform fundamentally. Merely investment was just like killing the goose that lays the golden eggs which means it couldn't develop for a long time. It's a must to have a long-term development view and combine all power that can develop to change its economy form.

Zheng Lanxiang and Zhou Jie(2014) considered that with the development of Chinese economy, people's ability of calculate have improved rapidly, application of computers showed its universality, software could work out relevant data such as operating performance. Recent years, the problem of the structure of commercial banks has become a hot topic because of the nature of them. Many scholars thought that structures of commercial banks affected its performance but others didn't think so. Therefore, we need to figure out whether or not the structure of a commercial bank affected its performance. If the answer is positive, a large-scale reform on the structure of commercial banks is needed, which conforms to the $13^{\text {th }}$ Five Year Plan that newly issued in 2016. If the answer is negative, the reform may died down and keep present model of commercial banks and continue its basic operation model to 
maintain the status quo.

Chen Weixiong(2015) did a survey on business banks in Shandong and Henan and did model analyses according to the data. Its contents had two points. Firstly, stockholders of state-owned banks held large stocks and rights were too concentrated. Secondly, number of directors was mainly related to investment.

\subsection{Purposes and significance of the research}

On the basis of the background above, this research had following purposes:

(a) Get comprehensive operating performance according to operating performance return on equity, non- performing loan ratio and liquidity ratio using factor analysis.

(b) Analyze the effect that capital structures of banks have on operating performance of commercial banks.

(c) Analyze the effect that capital structures of banks have on the operating performance of commercial banks.

(d) Discuss about how to improve capital structures of banks.

Whether or not capital structures of banks had effect on operating performance and did good to the development of banks were both topics of the research. Main object of the research was the effect that capital structures of commercial banks had on operating performance, which not only conformed to present research hotspot, but also had some meaning for instruction of enhancing the ability of commercial banks to resist the risk and improving operating performance.

\subsection{Contents and methods of the research}

Main contents of the research included:

(a) What effect did capital structures of banks had on operating performance? Was it doing good or bad to development?

(b) Suggestions on improving operating performance of commercial banks.

Main methods of the research included:

(a) Literature research 
This method was used to know about research trends in this area and confirm the emphasis and methods of the research by reading related literature about the effect capital structures of banks had on operating performance.

(b) Empirical analyses

According to data of China Banking Regulatory Commission, this paper selected return on equity, non-performing loan ratio and liquidity ratio as variables to measure business performance of banks, and also selected core (tier 1) capital adequacy ratio, assets-liability ratio and capital adequacy ratio as indexes and factors. This paper used SPSS19.0, factor analysis and regression analyses to calculate operating performance of banks and their long-term plans. Conclusion was drew by scientific calculation so as to settle and finish this subject.

\subsection{Introduction of basic concepts and methods of analyses}

Capital structure: in a broad sense, it is start-up capital or security capital of a company; in a narrow sense, it is the numerator of the development of a company. The bigger it is, the higher the development coefficient is; the smaller it is, the poorer the ability of developing is.

Operating performance: it is the social value of a company by its own efforts, mainly in the aspect of profitability, debt paying ability, security in the capital and capital liquidity in a given period.

Factor analysis: it is a method to calculate and predict initial variables. This method can owe final results to some specific factors and analyze by replacing initial variables with these common factors. It is easier to explain and analyze each kind of complicated problem to the point and it is considered as the most commonly used statistical method.

The model of factor analysis is:

$\mathrm{Xi}=\mathrm{AFi}+\varepsilon(\mathrm{i}=1,2,3 \ldots \mathrm{n})$

Formula

$\mathrm{Xi}$ represents initial indexes

Fi represents common factors of $\mathrm{Xi}$

A represents factor loading matrix 
$\varepsilon$ represents special factors

$$
A=\left[\begin{array}{l}
a_{11} a_{12} \ldots \ldots a_{1 m} \\
a_{21} a_{22} \ldots \ldots a_{2 m} \\
\ldots \ldots \ldots \ldots \ldots . . . \\
a_{p 1} a_{p 2} \ldots \ldots . a_{p m}
\end{array}\right] \text { Formula }(2.2)
$$

When using factor analysis, KMO test and Bartless test are test indexes that are used to judge whether measured objects are suitable for factor analysis and evaluate validity of measured objects. Generally, if the KMO test value is over 0.9 , this means the measured scale is especially suitable for factor analysis; if the KMO test value is between 0.8 and 0.9 , this means the measured scale is very suitable for factor analysis; if the KMO test value is between 0.7 and 0.8 , this means the measured scale is suitable for factor analysis; if the KMO test value is between 0.6 and 0.7 , this means the measured scale is relatively suitable for factor analysis; if the KMO test value is between 0.5 and 0.6 , this means the measured scale is barely suitable for factor analysis; if the KMO test value is below 0.5 , this means the measured scale is not suitable for factor analysis. Only when passing the test of Bartlett spherical test statistic and meeting the condition that significance probability is not higher than significance level, measured scales can be suitable for factor analysis.

Regression analyses is a method which calculates one variable (explained variable) on the basis of another variable (explaining variable) by certain data collection, according to mathematical relation, bringing a variable's value into mathematical formulas, through multiple calculation and tests and getting the answer, finally knowing the relation between two variables on the basis of the answer in order to analyze the relation among variables.

Common regression model is showed in formula 2.3

$y=\alpha+\beta x_{1}+\varepsilon$

Formula (2.3)

$y$ represents dependent variables, which is also called explained variables

$x$ represents independent variables, which is also called explaining variables

$\alpha$ represents constant term

$\varepsilon$ represents stochastic disturbance 
Getting the fitted equation through regression analyses, coefficient in front of the independent variable represents the effect degree which this independent variable has on dependent variable, the larger this coefficient is, the greater effect this independent variable has on dependent variable. Positive or negative value of the coefficient represents relation between two variables, if the coefficient is positive, two variables have the ration of mutual promotion; if the coefficient is negative, two variables have the relation of mutual obstruction. Steps of regression analyses are:

(a) Determine explaining variables and explained variables in the equation of linear regression.

(b) Determine the factors that need to be explained and factors that are used to explain.

(c) Determine mathematical model. Select and determine correspondent mathematical model to show the relation between explained variables and explaining variables on the basis of scatter diagram and correlation analyses of dependent variables and independent variables.

(d) Build regression model. Build correspondent regression equation on the basis of the mathematical model above.

(e) Test the regression equation. Calculate and predict the answer we need according to the equation in order to be used in this paper.

\section{Effect that capital structures of commercial banks have on operation performance}

\subsection{Selection of samples and variables}

The object of this paper was the effect that capital structure of commercial banks have on operating performance. In consideration of the convenience, generalizability and authority of the acquisition of the data of samples and variables, the data in this paper were data of supervision indexes of operating performance of Chinese commercial banks that were issued on official website by China Banking Regulatory Commission. Time was selected from the first quarter of 2011 to the third quarter of 2015.

According to the definition of capital structures and operating performance above, this paper selected assets-liability ratio, core (tier 1) capital adequacy ratio as indexes to reflect capital structure of commercial banks. The reason for the selection of variables was that composition of capital for commercial banks could be divided into two kinds, they were core capital and supplementary capital, they were also known as tier 1 capital and tier 2 capital. Because of the difficulty in acquiring tier 2 capital indexes, capital structures of commercial banks were replaced with tier one capital adequacy ratio and overall capital adequacy ratio. Return on assets, non-performing loan ratio and liquidity ratio were selected as indexes to measure 
operating performance of commercial banks. Data of each index was showed in Table 1.

Table 1. Data of indexes of capital structures and operating performance of commercial banks

\begin{tabular}{|c|c|c|c|c|c|c|}
\hline \multirow[b]{2}{*}{ Time } & \multicolumn{3}{|c|}{ Indexes of operating performance } & \multicolumn{3}{|c|}{ Indexes of capital structures } \\
\hline & $\begin{array}{l}\text { Non-perform } \\
\text { ing loan ratio }\end{array}$ & $\begin{array}{l}\text { Return on } \\
\text { assets }\end{array}$ & $\begin{array}{l}\text { Liquidity } \\
\text { ratio }\end{array}$ & $\begin{array}{l}\text { Assets-liabilit } \\
\text { y ratio }\end{array}$ & $\begin{array}{ll}\text { Tier } & 1 \\
\text { capital } & \\
\text { adequacy } \\
\text { ratio }\end{array}$ & $\begin{array}{l}\text { Capital } \\
\text { adequac } \\
\text { y ratio }\end{array}$ \\
\hline $2011 / 03$ & $1.1 \%$ & $1.4 \%$ & $41.3 \%$ & $93.98 \%$ & $9.8 \%$ & $12.2 \%$ \\
\hline $2011 / 06$ & $1.0 \%$ & $1.4 \%$ & $42.0 \%$ & $94.13 \%$ & $9.9 \%$ & $11.8 \%$ \\
\hline $2011 / 09$ & $0.90 \%$ & $1.40 \%$ & $42.80 \%$ & $93.78 \%$ & $10.1 \%$ & $12.3 \%$ \\
\hline $2011 / 12$ & $1.00 \%$ & $1.30 \%$ & $43.20 \%$ & $93.76 \%$ & $10.2 \%$ & $12.7 \%$ \\
\hline $2012 / 03$ & $0.94 \%$ & $1.43 \%$ & $45.66 \%$ & $93.79 \%$ & $10.31 \%$ & $12.74 \%$ \\
\hline $2012 / 06$ & $0.94 \%$ & $1.41 \%$ & $46.69 \%$ & $93.92 \%$ & $10.41 \%$ & $12.91 \%$ \\
\hline $2012 / 09$ & $0.95 \%$ & $1.39 \%$ & $45.23 \%$ & $93.72 \%$ & $10.58 \%$ & $13.03 \%$ \\
\hline $2012 / 12$ & $0.95 \%$ & $1.28 \%$ & $45.83 \%$ & $93.67 \%$ & $10.62 \%$ & $13.25 \%$ \\
\hline $2013 / 03$ & $0.96 \%$ & $1.37 \%$ & $45.36 \%$ & $93.65 \%$ & $9.85 \%$ & $12.28 \%$ \\
\hline $2013 / 06$ & $0.96 \%$ & $1.38 \%$ & $43.68 \%$ & $93.64 \%$ & $9.85 \%$ & $12.24 \%$ \\
\hline 2013/09 & $0.97 \%$ & $1.36 \%$ & $42.80 \%$ & $93.54 \%$ & $9.87 \%$ & $12.18 \%$ \\
\hline
\end{tabular}


Table 1, cont.

\begin{tabular}{|l|l|l|l|l|l|l|}
\cline { 2 - 7 } $2013 / 12$ & $1.00 \%$ & $1.27 \%$ & $44.03 \%$ & $93.47 \%$ & $9.95 \%$ & $12.19 \%$ \\
\hline $2014 / 03$ & $1.04 \%$ & $1.40 \%$ & $46.29 \%$ & $93.24 \%$ & $10.04 \%$ & $12.13 \%$ \\
\hline $2014 / 06$ & $1.08 \%$ & $1.37 \%$ & $47.52 \%$ & $93.40 \%$ & $10.13 \%$ & $12.4 \%$ \\
\hline $2014 / 09$ & $1.16 \%$ & $1.35 \%$ & $48.53 \%$ & $93.08 \%$ & $10.47 \%$ & $12.93 \%$ \\
\hline $2014 / 12$ & $1.25 \%$ & $1.23 \%$ & $46.44 \%$ & $92.8 \%$ & $10.76 \%$ & $13.18 \%$ \\
\hline $2015 / 03$ & $1.39 \%$ & $1.29 \%$ & $47.46 \%$ & $92.67 \%$ & $10.95 \%$ & $13.13 \%$ \\
\hline $2015 / 06$ & $1.50 \%$ & $1.23 \%$ & $46.18 \%$ & $92.96 \%$ & $10.79 \%$ & $12.95 \%$ \\
\hline & $1.59 \%$ & $1.20 \%$ & $46.16 \%$ & $92.76 \%$ & $10.99 \%$ & $13.15 \%$ \\
\hline
\end{tabular}

\subsection{Data processing}

In order to get comprehensive operating performance indexes of commercial banks, factor analysis was used in return on assets, non-performing loan ratio and liquidity ratio that represented operating performance of banks in this paper and got overall business performance.

Import the data of return on assets, non-performing loan ratio and liquidity ratio into SPSS19.0, conduct factor analysis on these indexes and get KMO value and Bartlett value. It was showed in Table 2. The KMO value is 0.567 , the sig. value of Bartlett spherical test is 0.001 . 
Table 2. KMO test and Bartlett test

\begin{tabular}{|l|l|l|}
\hline \multicolumn{2}{|l|}{ Took enough Kaiser-Meyer-Olkin as samples } & .567 \\
\hline & Approximate chi-square & 15.805 \\
\cline { 2 - 4 } Bartlett spherical test & df & 3 \\
\cline { 2 - 4 } & Sig. & .001 \\
\hline
\end{tabular}

Extract one common factor by factor analysis which was showed in Table 3.

Table 3. component matrix ${ }^{a}$

\begin{tabular}{|l|l|}
\hline \multirow{2}{*}{} & Component \\
\cline { 2 - 2 } & 1 \\
\hline Non-performing loan ratio & \\
\hline & .914 \\
\hline Return on assets & -.869 \\
\hline Liquidity ratio & .627 \\
\hline
\end{tabular}

Method of extracting : main component

a. one kind of component had been extracted 
The data in Table 4 showed that the common factor which had been extracted can explain $66.092 \%$ information of initial variables and showed original data information well.

Table 4. Total variance of explaining

\begin{tabular}{|c|c|c|c|c|c|c|}
\hline \multirow{2}{*}{ Component } & \multicolumn{3}{|c|}{ Initial value } & \multicolumn{3}{|c|}{ Extract the square } \\
\hline & $\begin{array}{l}\text { Summing } \\
\text { value }\end{array}$ & $\begin{array}{l}\text { Percentage } \\
\text { variance }\end{array}$ & $\begin{array}{l}\text { of Total } \\
\text { percentage }\end{array}$ & $\begin{array}{l}\text { Summing } \\
\text { value }\end{array}$ & $\begin{array}{l}\text { Percentage } \\
\text { variance }\end{array}$ & $\begin{array}{l}\text { of Total } \\
\text { percentage }\end{array}$ \\
\hline 1 & 1.983 & 66.092 & 66.092 & 1.983 & 66.092 & 66.092 \\
\hline 2 & .771 & 25.708 & 91.800 & & & \\
\hline 3 & .246 & 8.200 & 100.000 & & & \\
\hline
\end{tabular}

\subsection{Empirical analyses}

Set assets-liability ratio, core ( tier 1 ) capital adequacy ratio and capital adequacy ratio as explaining variables, represented by $\mathrm{X} 1, \mathrm{X} 2$ and $\mathrm{X} 3$; set common factors that had been extracted from the factor analysis of operating performance of banks above as explained variable, which was represented by Y. Build regression model of capital structure and operating performance which is showed in formula 3.1

$y=\alpha_{1} x_{1}+\alpha_{2} x_{2}+\alpha_{3} x_{3}+\beta$

Formula

Import data into SPSS 19.0 to conduct regression analyses on capital structures and operating performance, get fitting situation of the model. Results were showed in Table 5. Adjusted $\mathrm{R}^{2}$ in this model was 0.857 , which reflected that $85.7 \%$ of the change of operating performance of commercial banks could be explained by the change of capital structures. Fitting situation was fine. 
Table 5. Fitting situation of the model

\begin{tabular}{|l|l|l|l|l|}
\hline & $\mathrm{R}$ & $\mathrm{R}^{2}$ & Adjusted $\mathrm{R}^{2}$ & Estimated error \\
\hline 1 & $.938^{\mathrm{a}}$ & .881 & .857 & .37862533 \\
\hline
\end{tabular}

The Sig. value of the model was 0.000 from the angle of Anova ${ }^{b}$ test ( it was showed in Table 6), which reflected that the model had meaning for statistics.

Table 6. Anova ${ }^{\mathrm{b}}$ results of the model

\begin{tabular}{|c|c|c|c|c|c|c|}
\hline \multicolumn{2}{|c|}{ Model } & \multicolumn{2}{|c|}{ Quadratic sumdf } & \multirow{2}{*}{$\begin{array}{l}\text { Mean } \\
\text { square } \\
5.283\end{array}$} & \multirow{2}{*}{\begin{tabular}{|l} 
\\
36.854
\end{tabular}} & \multirow{2}{*}{$\begin{array}{l}\text { Sig. } \\
.000^{\mathrm{a}}\end{array}$} \\
\hline \multirow{3}{*}{1} & Regression & 15.850 & 3 & & & \\
\hline & $\begin{array}{l}\text { Residual } \\
\text { error }\end{array}$ & 2.150 & 15 & 143 & & \\
\hline & $\begin{array}{l}\text { Summing } \\
\text { value }\end{array}$ & 18.000 & 18 & & & \\
\hline
\end{tabular}

b. Dependent variables: operating performance of banks

The final fitting results were showed in Table 7. The results were: assets-liability ratio was -1.462, core (tier 1) capital adequacy ratio was 1.124 and capital adequacy ratio was 0.189 . these values showed that assets-liability ratio and capital adequacy ratio had negative correlation with operating performance of banks, tier 1 capital adequacy ratio had positive correlation with operating performance of banks. In other words, the higher proportion of capital which were acquired by debts, the lower operating performance was. In a capital structure, if the proportion of core (tier 1) capital got higher, before assets of depositors and creditors in commercial banks suffered a loss, this bank could undertake largely loss with its own capital, ability of the commercial bank to get operation performance would be stronger. From the value of significant statistic Sig., we could see that Sig. values of assets-liability ratio, core (tier 1) capital adequacy ratio and capital adequacy ratio were 0.000, 0.134 and 0.73 , which reflected that assets-liability ratio had significant effect on operating performance 
of banks, core (tier 1) capital adequacy ratio and capital adequacy ratio didn't have significant effect on operating performance of banks. Formula 3.2 was final regression equation on the basis of model of regression.

$y_{1}=-1.462 x_{1}+1.124 x_{2}-0.189 x_{3}+127.501$

Formula (3.2)

Table 7. Coefficient of regression model ${ }^{\mathrm{a}}$

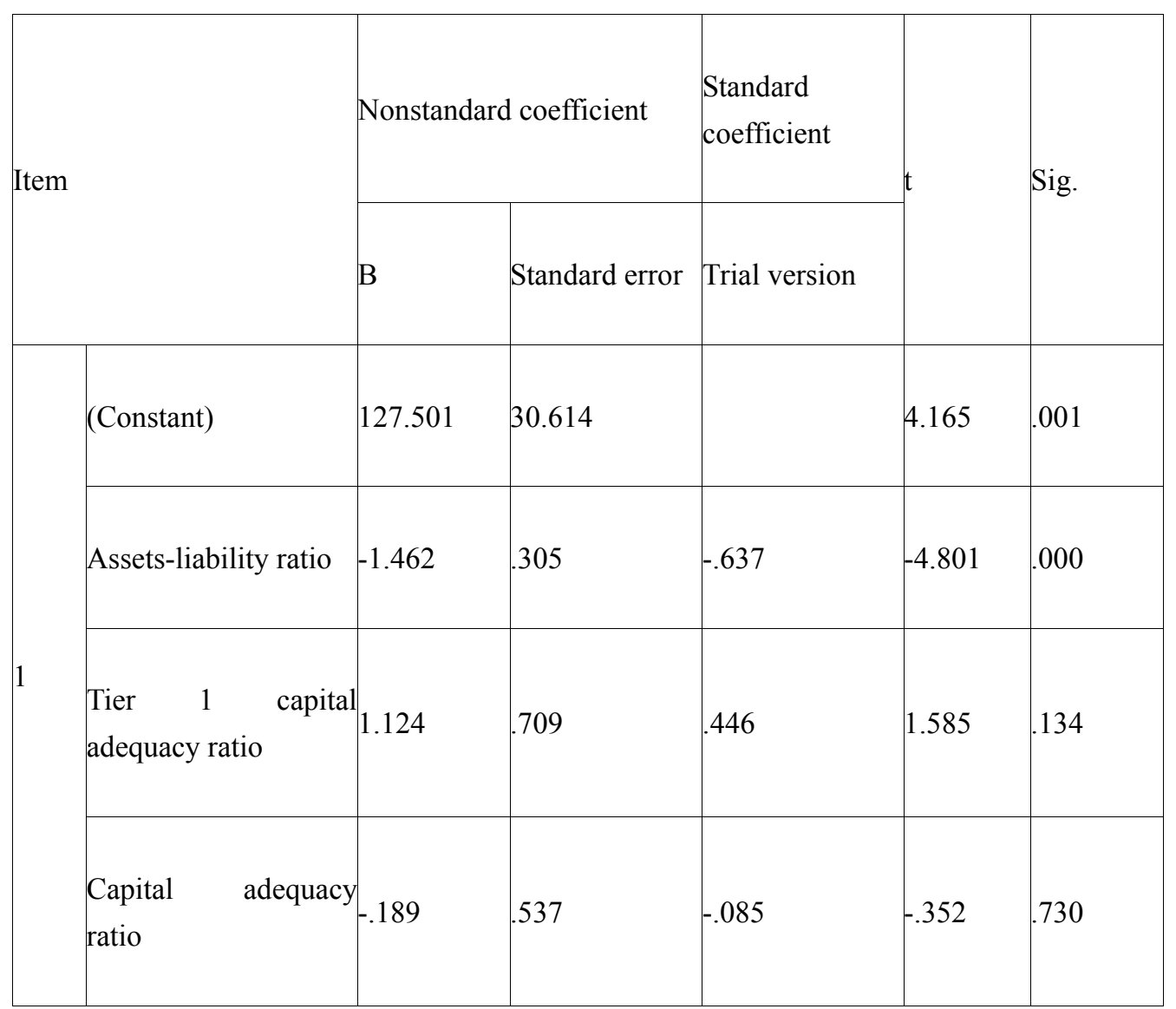

\section{Effect that capital structures of commercial banks had on operating performance}

In last section, this paper analyzed the effect that capital structures of banks had on overall operating performance. But ways to measure operating performance had many aspects. So we needed to further analyze concrete effects that capital structures had on operating performance of banks. Therefore, in this section, regression analyses would be conducted to the effects that capital structures of banks had on sub-indexes that reflected profitability, security and liquidity of capital of banks such as return on assets, non-performing loan ratio and liquidity ratio in order to get concrete effects that capital structures had on operating performance of banks. 


\subsection{Analyses of effects that capital structures of banks had on profitability of assets}

Select assets-liability ratio, core (tier 1) capital adequacy ratio and capital adequacy ratio as explaining variables that were represented by $\mathrm{X} 1, \mathrm{X} 2$ and $\mathrm{X} 3$; select return on assets as explained variable which was represented by $\mathrm{Y} 1$. The regression model of capital structures and profitability was showed in formula 4.1

$y_{1}=\alpha_{1} x_{1}+\alpha_{2} x_{2}+\alpha_{3} x_{3}+\beta_{1}$

Formula

Import data into SPSS 19.0 to conduct regression analyses on capital structures and profitability of assets, get fitting situation of the model. Results were showed in Table 8 . Adjusted $\mathrm{R}^{2}$ in this model was 0.475 , which reflected that $47.5 \%$ of the change of profitability of commercial banks could be explained by the change of capital structures. Building of model could be accepted

Table 8. Fitting situation of the model of capital structures and profitability of assets of banks

\begin{tabular}{|l|l|l|l|l|}
\hline Item & $\mathrm{R}$ & $\mathrm{R}^{2}$ & Adjusted $\mathrm{R}^{2}$ & Estimated error \\
\hline 1 & $.750^{\mathrm{a}}$ & .563 & .475 & $.05127 \%$ \\
\hline
\end{tabular}

The Sig. value of the model was 0.005 from the angle of Anova ${ }^{b}$ test. 
Table 9. Anova ${ }^{\mathrm{b}}$ results of the model of capital structures and profitability of assets of banks

\begin{tabular}{|l|l|l|l|l|l|l|}
\hline \multicolumn{2}{|l|}{ Model } & $\begin{array}{l}\text { Quadratic } \\
\text { sum }\end{array}$ & $\mathrm{df}$ & $\begin{array}{l}\text { Mean } \\
\text { aquare }\end{array}$ & $\mathrm{F}$ & Sig. \\
\hline \multirow{2}{*}{1} & Regression & .051 & 3 & .017 & 6.438 & $.005^{\mathrm{a}}$ \\
\cline { 2 - 7 } & $\begin{array}{l}\text { Residual } \\
\text { error }\end{array}$ & .039 & 15 & .003 & & \\
\cline { 2 - 6 } & $\begin{array}{l}\text { Summing } \\
\text { value }\end{array}$ & .090 & 18 & & & \\
\hline
\end{tabular}

The final fitting results were showed in Table 10. The results were: assets-liability ratio was 0.09 , core (tier 1) capital adequacy ratio was -0.029 and capital adequacy ratio was -0.017 . These values showed that they had positive correlation with each other, tier 1 capital adequacy ratio and capital adequacy ratio had negative correlation with profitability of assets of banks. In other words, the higher proportion of capital which was acquired by debts, the higher profitability was. In a capital structure, if the proportion of core (tier 1) capital got higher, its proportion of supplementary capital would be higher, possibility of the commercial bank to earn would be lower. From the value of significant statistic Sig., we could see that Sig. values of assets-liability ratio, core ( tier 1) capital adequacy ratio and capital adequacy ratio were $0.046,0.768$ and 0.817 , which reflected that assets-liability ratio had significant effect on profitability of assets of banks, core (tier 1) capital adequacy ratio and capital adequacy ratio didn't have significant effect on profitability of assets of banks. Formula 4.2 was final regression equation on the basis of model of regression.

$y_{1}=0.9 x_{1}-0.029 x_{2}-0.017 x_{3}-6.522 \quad$ Formula (4.2) 
Table 10. Model of capital structures and profitability of assets of banks

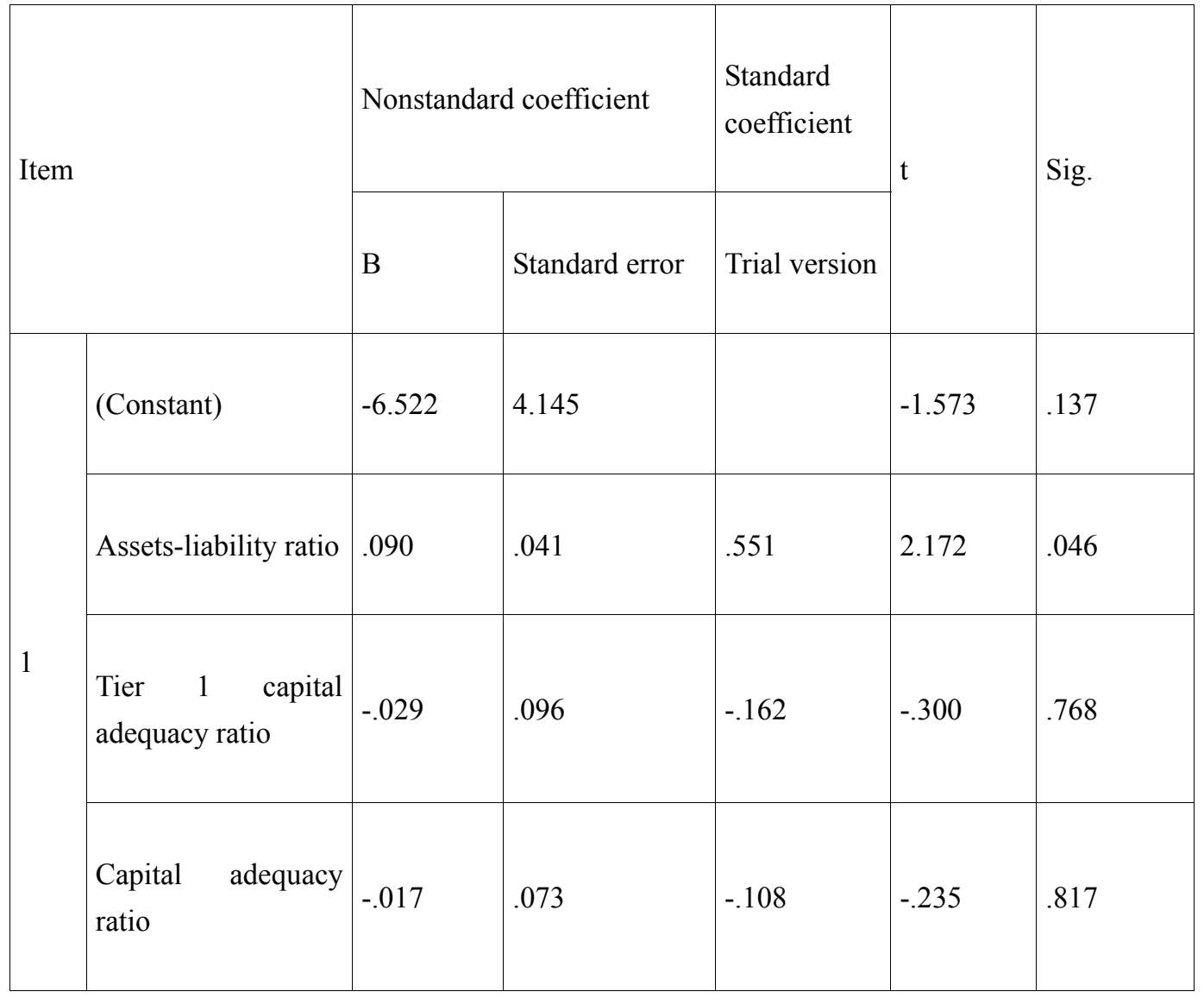

a. dependent variable: return on assets

\subsection{Analyses of effects that capital structures of banks had on security of assets}

Select assets-liability ratio, core (tier 1) capital adequacy ratio and capital adequacy ratio as explaining variables that were represented by X4, X5 and X6; select non-performing loan ratio as explained variable which was represented by Y2. The regression model of capital structures and security of assets was showed in formula 4.3.

$y_{2}=\alpha_{4} x_{4}+\alpha_{5} x_{5}+\alpha_{6} x_{6}+\beta_{2}$

Formula

(4.3) 
Import data into SPSS 19.0 to conduct regression analyses on capital structures and security of assets, get fitting situation of the model. Results were showed in Table 11. Adjusted $\mathrm{R}^{2}$ in this model was 0.732 , which reflected that $73.2 \%$ of the change of security of assets of commercial banks could be explained by the change of capital structures. Building of model was perfect.

Table 11. Security of assets and capital structures of banks

\begin{tabular}{|l|l|l|l|l|}
\hline Item & $\mathrm{R}$ & $\mathrm{R}^{2}$ & Adjusted $\mathrm{R}^{2}$ & Estimated error \\
\hline 1 & $.881^{\mathrm{a}}$ & .777 & .732 & $.10457 \%$ \\
\hline
\end{tabular}

The Sig. value of the model was 0.000 from the angle of Anova ${ }^{b}$ test which reflected that the model had meaning for statistics.

Table 12. Anova ${ }^{\mathrm{b}}$ results of the model of capital structures and security of assets of banks

\begin{tabular}{|c|c|c|c|c|c|c|}
\hline \multicolumn{2}{|c|}{ Model } & Quadratic & df & Mean & $\mathrm{F}$ & Sig. \\
\hline \multirow{3}{*}{1} & Regression & .570 & 3 & .190 & 17.376 & $.000^{\mathrm{a}}$ \\
\hline & $\begin{array}{l}\text { Residual } \\
\text { error }\end{array}$ & .164 & 15 & .011 & & \\
\hline & $\begin{array}{l}\text { Summing } \\
\text { value }\end{array}$ & .734 & 18 & & & \\
\hline
\end{tabular}

The final fitting results were showed in Table 13. The results were: assets-liability ratio was -0.235 , core (tier 1) capital adequacy ratio was 0.511 and capital adequacy ratio was -0.322 . These values showed that they had negative correlation with each other. In other words, the 
higher proportion of capital which was acquired by debts, the lower security of assets was. In a capital structure, if the proportion of core (tier 1) capital got higher, ability of commercial capital would be stronger, security coefficient would be higher. From the value of significant statistic Sig., we could see that Sig. values of assets-liability ratio, core( tier 1) capital adequacy ratio and capital adequacy ratio were $0.014,0.02$ and 0.047 , which reflected that assets-liability ratio, core (tier 1) capital adequacy ratio and capital adequacy ratio didn't have significant effect on security of assets of banks. Formula 4.4 was final regression equation on the basis of model of regression.

$y_{2}=-0.235 x_{4}+0.511 x_{5}-0.322 x_{6}-21.833 \quad$ Formula 4.4

Table 13. Model of capital structures and security of assets of banks

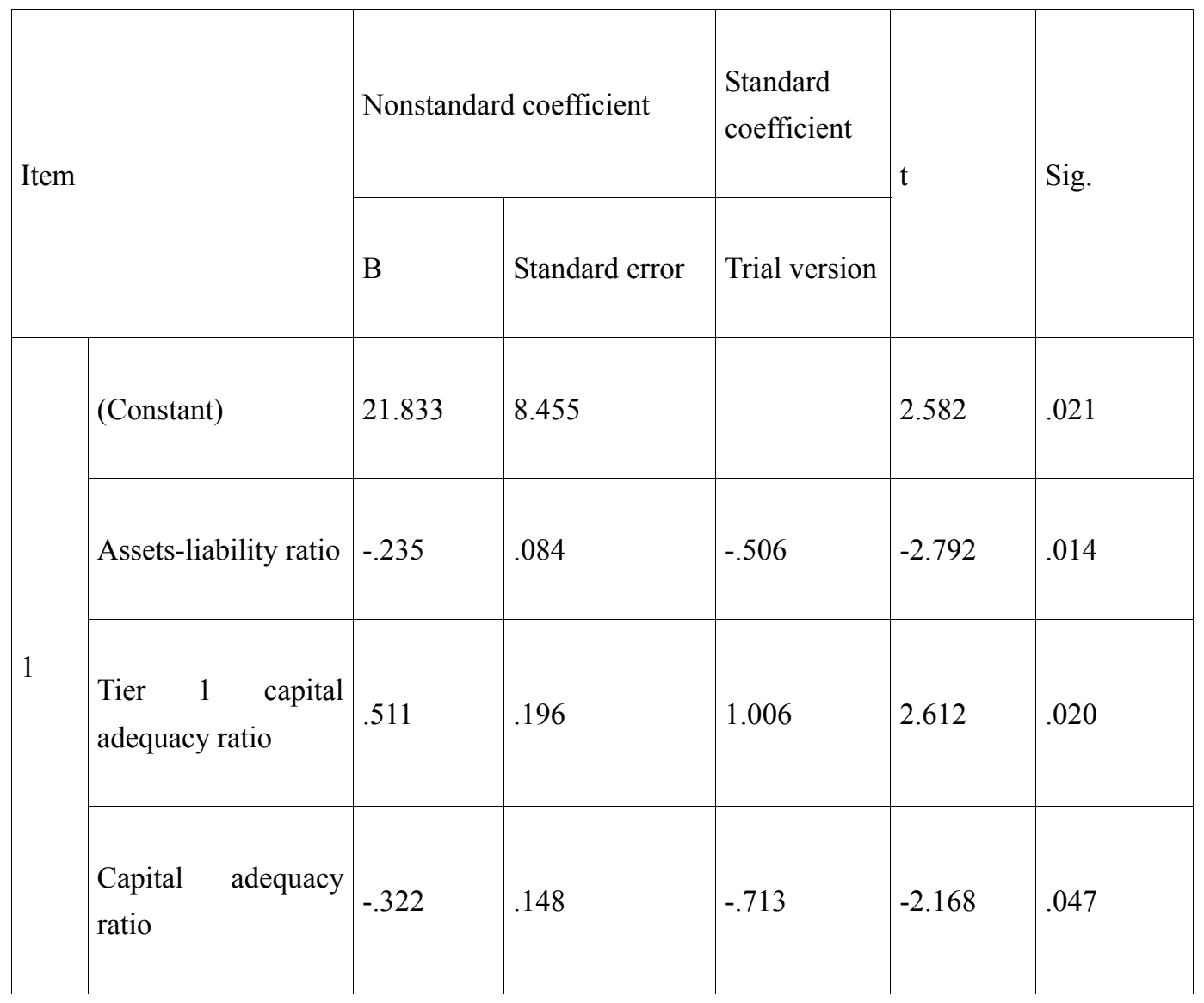

a. dependent variable: non-performing loan ratio 


\subsection{Analyses of effects that capital structures of banks had on liquidity of assets}

Select assets-liability ratio, core (tier 1 ) capital adequacy ratio and capital adequacy ratio as explaining variables that were represented by $\mathrm{X} 7, \mathrm{X} 8$ and $\mathrm{X} 9$; select return on assets as explained variable which was represented by Y3. The regression model of capital structures and liquidity of assets was showed in formula 4.5 .

$$
y_{3}=\alpha_{7} x_{7}+\alpha_{8} x_{8}+\alpha_{9} x_{9}+\beta_{3}
$$

Formula

Import data into SPSS 19.0 to conduct regression analyses on capital structures and liquidity of assets, get fitting situation of the model. Results were showed in Table 14. Adjusted $\mathrm{R}^{2}$ in this model was 0.468 , which reflected that $46.8 \%$ of the change of liquidity of assets of commercial banks could be explained by the change of capital structures.

Table 14. Liquidity of assets and capital structures of banks

\begin{tabular}{|l|l|l|l|l|}
\hline Item & $\mathrm{R}$ & $\mathrm{R}^{2}$ & Adjusted $\mathrm{R}^{2}$ & Estimated error \\
\hline 1 & $.746^{\mathrm{a}}$ & .556 & .468 & $1.47490 \%$ \\
\hline
\end{tabular}

The Sig. value of the model was 0.006 from the angle of Anova ${ }^{b}$ test (it was showed in Table 15.), which reflected that the model had meaning for statistics.

\begin{tabular}{|c|c|c|c|c|c|c|}
\hline \multicolumn{2}{|c|}{ Model } & \multirow{2}{*}{$\begin{array}{l}\text { Quadratic } \\
\text { sum } \\
\\
40.919\end{array}$} & \multirow{2}{*}{\begin{tabular}{|l} 
df \\
3
\end{tabular}} & \multirow{2}{*}{$\begin{array}{l}\text { Mean } \\
\text { aquare } \\
13.640\end{array}$} & \multirow{2}{*}{$\begin{array}{l}\text { F } \\
6.270\end{array}$} & \multirow{2}{*}{$\begin{array}{l}\text { Sig. } \\
\\
.006^{\mathrm{a}}\end{array}$} \\
\hline & Regression & & & & & \\
\hline \multirow[t]{2}{*}{1} & $\begin{array}{l}\text { Residual } \\
\text { error }\end{array}$ & 32.630 & 15 & 2.175 & & \\
\hline & $\begin{array}{l}\text { Summing } \\
\text { value }\end{array}$ & 73.549 & 18 & & & \\
\hline
\end{tabular}


Table 16. Model of capital structures and liquidity of assets of banks

\begin{tabular}{|c|c|c|c|c|c|c|}
\hline \multirow{2}{*}{\multicolumn{2}{|c|}{ Item }} & \multicolumn{2}{|c|}{ Nonstandard coefficient } & \multirow{2}{*}{$\begin{array}{l}\text { Standard } \\
\text { coefficient } \\
\text { Trial version }\end{array}$} & \multirow{2}{*}{$\mathrm{t}$} & \multirow{2}{*}{ Sig. } \\
\hline & & B & Standard error & & & \\
\hline \multirow{4}{*}{1} & (Constant) & 246.509 & 119.253 & & 2.067 & .056 \\
\hline & Assets-liability ratio & -2.378 & 1.187 & -.512 & -2.004 & .063 \\
\hline & $\begin{array}{l}\text { Tier } 1 \text { capital } \\
\text { adequacy ratio }\end{array}$ & -1.418 & 2.761 & -.279 & -.513 & .615 \\
\hline & $\begin{array}{l}\text { Capital adequacy } \\
\text { ratio }\end{array}$ & 2.809 & 2.092 & .622 & 1.343 & .199 \\
\hline
\end{tabular}

a. dependent variable: return on assets

The results were in Table 16. The results were: assets-liability ratio was -2.378 , core (tier 1 ) capital adequacy ratio was -1.418 and capital adequacy ratio was 2.809 . These values showed that they had negative correlation with each other. In other words, the higher proportion of capital which was acquired by debts, the lower liquidity of assets was. In a capital structure, if the proportion of core (tier 1) capital got higher, the liquidity of assets would be poorer. We could see that Sig. values of assets-liability ratio, core ( tier 1) capital adequacy ratio and capital adequacy ratio were $0.063,0.615$ and 0.199 , which reflected that assets-liability ratio, core (tier 1) capital adequacy ratio and capital adequacy ratio didn't have significant effect on banks. Formula 4.6 was final regression equation on the basis of model of regression. 
$y_{2}=-2.378 x_{7}-1.418 x_{8}+2.809 x_{9}+246.509 \quad$ Formula 4.6

\section{Conclusions}

This paper used SPSS19.0, selected return on assets, non-performing loan ratio and liquidity ratio of commercial banks from the first quarter of 2011 to the third quarter of 2015 as indexes to measure operating performance of banks, selected assets-liability ratio, core (tier 1) capital adequacy ratio and capital adequacy ratio as indexes of capital structures of commercial bank, used factor analysis to calculate comprehensive operating performance of banks, built regression models of capital structures, comprehensive operating performance and subentry of operating performance to conduct empirical analyses and draw several conclusions:

(a) Assets- liability ratio and capital adequacy ratio had negative correlation with operating performance of banks, capital adequacy ratio and tier 1 capital adequacy ratio had negative correlation with operating performance of banks.

(b) Assets-liability ratio had positive correlation with profitability of assets, capital adequacy ratio and tier 1 capital adequacy ratio had negative correlation with profitability of assets.

(c) Assets-liability ratio, tier 1 capital adequacy ratio and capital adequacy ratio had negative correlation with security of assets.

(d) Assets-liability ratio, tier 1 capital adequacy ratio and capital adequacy ratio had negative correlation with liquidity of assets.

Calculation and prediction in this paper clearly showed that capital structures of banks were largely related to operating performance of banks. These 4 situations above spoke volume for concrete correlation among them. Therefore, according to current situation of capital structures of Chinese commercial banks, banks should arrange core capital and supplementary capital rationally when operating; they shouldn't expand scale of capital by debts or financing blindly in order to try their best to reduce negatives effects that capital structures had on security, liquidity and profitability of assets. It was a must to step on the road of diversified sources of investment, manage investment sources effectively, build risk-warning mechanism and take control of possibility of financial risk.

\section{Acknowledgement}

The research is supported by National Natural Science Foundation of China (71101076), MOE Layout Foundation of Humanities and Social Sciences (10YJA630147), and Natural Science Foundation of Nantong University(10ZY002) 


\section{References:}

Buser, S., Chen, A., Kane, E., Federal Deposit Insurance, Regulatory Policy, and Optimal Bank Capital, Journal of Finance, The . 1981.

Klein, M.A., A Theory of the Banking Firm. Journal of Money, Credit and Banking . 1971.

John J. Pringle. The Capital Decision in Commercial Banks. The Journal of Finance . 1974.

Loretta, J. Mester., Discussants'Comments on Berg and McAllister and McManus, Journal of Banking and Finance, 1993.

Fogelberg, L. \& J. M., Griffith.Control and bank performance, Journal of Financial \& Strategic Decisions, 2000.

Williarnson, Oliver, E., Corporate Finance and Corporate Governance, Journal of Finance, 1988.

Diamond, D. W. and Philip, HD, Bank Runs, Deposit Insurance, and Liquidity, Journal of Politics . 1983.

Merton Robert, C., and Andre, F. Perold, Theory of risk capital in financial firms, Journal of Applied Corporate Finance . 1993. 